\title{
SPATIAL AND TEMPORAL VARIATIONS IN SURFACE WATER QUALITY OF THE DAM RESERVOIR IN THE GUENITRA BASIN, ALGERIA
}

\author{
F. Fekrache ${ }^{1, *}$ and K. Boudeffa ${ }^{1}$ \\ ${ }^{1}$ Department of Biology, University of 20 August 1955, Skikda21000, Algeria. \\ *E-mail: f.fekrache@univ-skikda.dz
}

\begin{abstract}
The objective of the study was to assess physicochemical parameters of Guenitra dam. We investigate its water quality from March to May 2017 by monitoring some important physical (EC, turbidity and Total Hardness) and chemical ( $\mathrm{pH}, \mathrm{Ca}^{+2}, \mathrm{Mg}^{+2}, \mathrm{Cl}^{-}, \mathrm{SO}_{4}{ }^{-2}$ and TDS) parameters and nutrients (nitrogen and phosphorus) contents. The results indicated that most of the physicochemical parameters from Guenitra basin were within or at the margin in comparison to the permissible limit of Algerian standards and WHO for drinking and irrigation water and therefore, may be suitable for domestic purposes, but it requires noticeable consideration due to extreme changes in climate and increase in pollution.
\end{abstract}

Keywords: Guenitra, Nutrients, Irrigation, Drinking, Turbidity

(c) RASĀYAN. All rightsreserved

\section{INTRODUCTION}

Water is a naturally circulating resource abundantly available on earth surface ${ }^{1}$.On the hydrological level, Algeria has limited, irregular and very unequally distributed natural resources. About $90 \%$ of the total surface flow estimated at 12.4 billion $\mathrm{m}^{3} /$ year is in the littoral region ${ }^{1}$. The construction of more than 30 dams during the last decade has increased the storage capacity of surface water to about 7 billion $\mathrm{m}^{3}$; only half of this mobilized volume is used for irrigation and domestic consumption purposes ${ }^{2,3}$. Available water quality data reveal that most of Algeria's water resources are polluted by uncontrolled discharges from municipal waters and untreated industrial effluents, urban and industrial wastewaters are everywhere being discarded in the natural environment and cause increasingly dangerous pollution for water resources and public health ${ }^{4}$.The city of Skikda has four (4) large dams in operation with a total initial capacity of $317 \mathrm{~mm}^{3}$, currently with the problems of siltation and others; they retain a total volume of 292 $\mathrm{mm}^{3}$ per year, destined for the drinking water supply of the various municipalities of the Skikda city, irrigation and industry. The dam of Guenitra locates in the town of OumToub it satisfies the needs of drinking water of the city of Skikda and its industrial zone. Its initial capacity is estimated at $120 \mathrm{~mm}^{3}$, currently, it can hold only $117 \mathrm{~mm}^{3}$ of water, and its regulatable volume is estimated at nearly $30 \mathrm{~mm}^{3}$ per year ${ }^{5}$.The wastewater of the town of OumToub and BeniOuelbeneis directly dumped in the rivers which contributed to the degradation of the water quality of the Guenitra dam. The objective of this work is to study the impact of these effluents on the chemistry of dam water. To achieve this goal, we conducted a hydrochemical study.

\section{Material and Methods}

\section{EXPERIMENTAL}

The Guenitra Dam is located in Skikda Province in the north-eastern part of Algeria. This dam has a dual purpose: it provides drinking water to the city of Skikda $37000 \mathrm{~m}^{3}$, surrounding agglomerations and the industrial area with $16000 \mathrm{~m}^{3}$, and it is intended to ensure the irrigation of the perimeters of Emdjez Edechich and the Saf-Saf valley with an area of 5650 hectares. The fill rate of the OumToub dam

Rasayan J. Chem., 12(2), 827-832(2019)

http://dx.doi.org/10.31788/RJC.2019.1225223

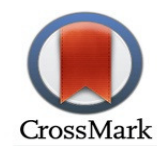


(Guenitra) reached the $75 \%$ threshold, is a water volume of 94 million cubic meters with a capacity of 125 million cubic meters. The total volume of the average contribution of all rivers to the dam is estimated at $55 \mathrm{hm}^{3}$ per year.The Guenitra dam is built on the bed ofFessariver, in a point of dimension $110 \mathrm{~m}$ and with a sub-watershed of about $202 \mathrm{~km}^{2}$.

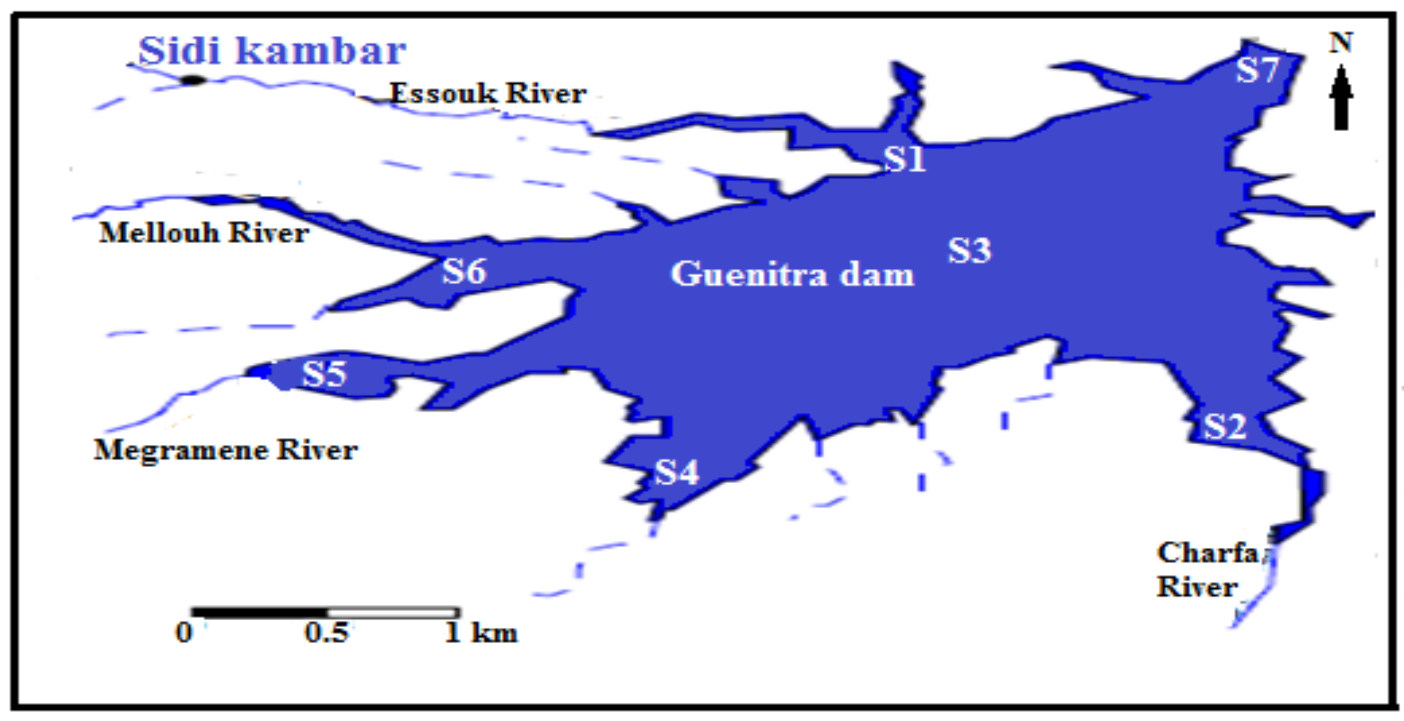

\section{Detection Method}

Fig.-1: Map of the Sampling Site Locations ( $S=$ site $)$.

Water samples were collected at monthly intervals betweenMarchand May 2017.Water samples for physico-chemicals properties analyses were frozen in polyethylene bottles and processed within two days from collection. In the laboratory, after filtration of the sample through Whatman GF/C glass filters $(0.5$ $\mathrm{mm}$ porosity) and stored at $4{ }^{\circ} \mathrm{C}$ until their analysis, which was accomplished within one week. Prior to sample collection, sampling device and containers were rinsed twice with the water to be sampled. 12 physicochemical parameters have been determined by the following standard and recommended methods of analysis ${ }^{6,7}$.Table-1 displays the variables measured and their units, the analytical techniques employed, and the abbreviations used henceforth. A total of 420 analysis were carried out (12 variables in 35 samples). Two replications of each analysis were performed and mean values were used for calculations.

Table-1: Physico-Chemical Parameters Determined and Analytical Techniques used

\begin{tabular}{|c|c|c|c|}
\hline Variable & Abbreviation & Analytical Technique & Unit \\
\hline $\mathrm{pH}$ & $\mathrm{pH}$ & Potentiometry/pH probe & pH unit \\
\hline Conductivity & $\mathrm{EC}$ & Conductometry & $\mu \mathrm{S} / \mathrm{cm}$ \\
\hline Total DissolvedSolids & TDS & Dryingat $1808 \mathrm{C} /$ weighing & $\mathrm{mg} / \mathrm{l}$ \\
\hline Hardness & THT & EDTA titrometry & $\mathrm{mg} \mathrm{CaCO} / \mathrm{l}$ \\
\hline Turbidity & TYR & Turbidometer & NTU \\
\hline Chloride & $\mathrm{Cl}^{-}$ & Mercury nitrated titrometry & $\mathrm{mg} / \mathrm{l}$ \\
\hline Sulphate & $\mathrm{SO}_{4}^{-2}$ & Spectrophotometry & $\mathrm{mg} / \mathrm{l}$ \\
\hline Magnesium & $\mathrm{Mg}^{+2}$ & EDTA titrometry & $\mathrm{mg} / \mathrm{l}$ \\
\hline Calcium & $\mathrm{Ca}^{+2}$ & EDTA titrometry & $\mathrm{mg} / \mathrm{l}$ \\
\hline Ammonium & $\mathrm{NH}_{4}^{+}$ & Spectrophotometry & $\mathrm{mg} / \mathrm{l}$ \\
\hline Nitrite & $\mathrm{NO}_{2}{ }^{-}$ & Spectrophotometry & $\mathrm{mg} / \mathrm{l}$ \\
\hline Phosphate & $\mathrm{PO}_{4}^{+3}$ & Spectrophotometry & $\mathrm{mg} / \mathrm{l}$ \\
\hline
\end{tabular}

\section{RESULTS AND DISCUSSION}

The physic-chemical characteristics provide a fair idea of the water quality in any water body. The result of the physicochemical characteristics of Guenitra dam water is summarized in Fig.-2.

\section{pH}

Aquatic organisms are affected by $\mathrm{pH}$, because most of their metabolic activities are $\mathrm{pH}$ dependent. Optimal $\mathrm{pH}$ range for sustainable aquatic life is $\mathrm{pH} 6.5-8.2^{8}$. thepH of an aquatic system is an important 
indicator of the water quality and the extent pollution in the watershed areas ${ }^{9}$. In unpolluted waters, $\mathrm{pH}$ is principally controlled by the balance between the carbon dioxide, carbonate and bicarbonate ions as well as other natural compounds such as humic and fluvic acids. Changes in $\mathrm{pH}$ can indicate the presence of certain effluents, particularly when continuously measured and recorded, together with the conductivity of a water body. Dial variations in $\mathrm{pH}$ can be caused by the photosynthesis and respiration cycles of algae in eutrophic waters. The $\mathrm{pH}$ of most natural waters is between 6.0 and 8.5, although lower values can occur in dilute waters high in organic content, and higher values in eutrophic waters, groundwater brines and salt lakes ${ }^{10}$. The $\mathrm{pH}$ ranged from 7.1 to 7.98. The parameter was in the permissible limit, hence water quality can be considered safe for domestic and agricultural purposes.

\section{Conductivity}

Conductivity is the measure of the capacity of a substance or solution to conduct electrical current through the water ${ }^{11}$. Total dissolved Conductivity is related to the concentrations of total dissolved solids and major ions. The conductivity of most freshwaters ranges from 10 to $1000 \mu \mathrm{S} / \mathrm{cm}$, but may exceed $1000 \mu \mathrm{S} / \mathrm{cm}$, especially in polluted waters, or those receiving large quantities of land run-off ${ }^{9}$. The levels of EC were within acceptable limits set by Algeria and the World Health Organization ranging from 525 to $1043 \mu \mathrm{S} / \mathrm{cm}$.

\section{Total Dissolved Salts}

The level of TDS was under the permissible limits, ranging from 53 to $489 \mathrm{mg} / \mathrm{l}$. Total dissolved solids are considered a major factor for the taste of water and for growth of plants..$^{11,12}$ The presences of total dissolved solids (TDS) in water resources also play a significant role to decide its suitability of water for different uses ${ }^{13}$; therefore, the water of Guenitra dam is suitable for irrigation and drinking. The level of TDS depends on several factors such as the geological character of the watershed, rainfall, and the amount of surface runoff.

\section{Turbidity}

The turbidity of any water sample is the reduction of transparency due to the presence of particulate matter such as lay or slit, finely divided organic matter, plankton and other microscopic organisms ${ }^{14}$. Turbidity of water is an important parameter, which influences the light penetration inside the water and thus affects the aquatic life. ${ }^{15,16}$ During the present study maximum turbidity was recorded in the month of May at Site 3 (50 NTU) and minimum in the month of April at Site 2 (0.97 NTU) which is lower than the standard allowable limits set by Algeria and the World Health Organization. The parameters were in permissible limits, hence water quality can be considered safe for domestic and agricultural purposes. The high turbidity level (50 NTU) at being attributed to soil erosion, surface runoff, and the contribution of suspended solids from domestic wastes. ${ }^{17}$

\section{Cations and Anions}

The results of cations $\mathrm{Ca}^{+2}$ and $\mathrm{Mg}^{+2}$ were found to be in the range of 32 to $90 \mathrm{mg} / \mathrm{l}$ and 160 to $340 \mathrm{mg}$, respectively. There are no suggested standards of $\mathrm{Ca}^{+2}$ and $\mathrm{Mg}^{+2}$ for drinking and irrigation water. Moreover, the total concentrations of $\mathrm{Ca}^{+2}$ and $\mathrm{Mg}^{+2}$ are referred to as hardness and it was observed that the total hardness was within standard limits of Algeria $(500 \mathrm{mg} / \mathrm{l})$. Chloride is considered a conservative chemical species in water, and is therefore considered a good indicator of the amount of effluent being discharged at any given time ${ }^{18}$. In addition, the concentration of some anions such as sulfates $\left(\mathrm{SO}_{4}{ }^{-2}\right)$ and chlorides $\left(\mathrm{Cl}^{-}\right)$between 20 to $400.93 \mathrm{mg} / \mathrm{l}$ and 35.5 to $213 \mathrm{mg} / \mathrm{l}$, respectively. Concentrations of all these anions were found to be under permissible limits set by the Algeria and WHO for drinking and irrigation water.

\section{Total Hardness}

Total hardness is a measure of the capacity of water to the concentration of calcium and magnesium in water and is usually expressed as the $\mathrm{mg} / \mathrm{l}$ of $\mathrm{CaCO}_{3}$ concentration ${ }^{19}$. Hardness is correlated with TDS (Total Dissolved Solids), it represents the total concentration of $\mathrm{Ca}^{+2}$ and $\mathrm{Mg}^{+2}$ ions, and is reported in equivalent $\mathrm{CaCO}_{3}$. Other ions $\left(\mathrm{Fe}^{+2}\right)$ may also contribute ${ }^{20}$. 
RASĀYAN J. Chem.

Vol. 12 | No. 2 |827 - 832| April - June | 2019
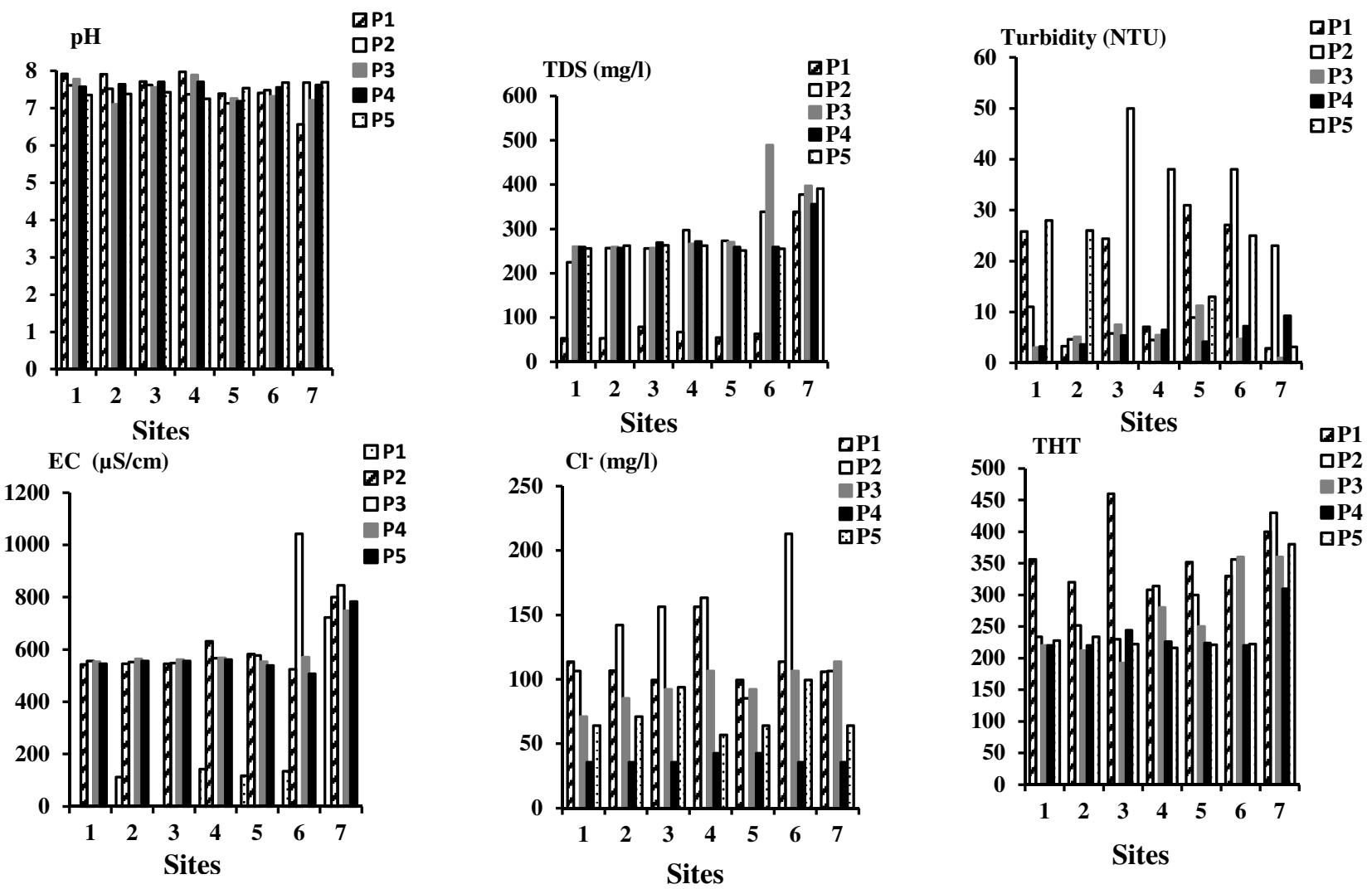

I deleted the title figure 3, I put a single title because all figures in the same page.
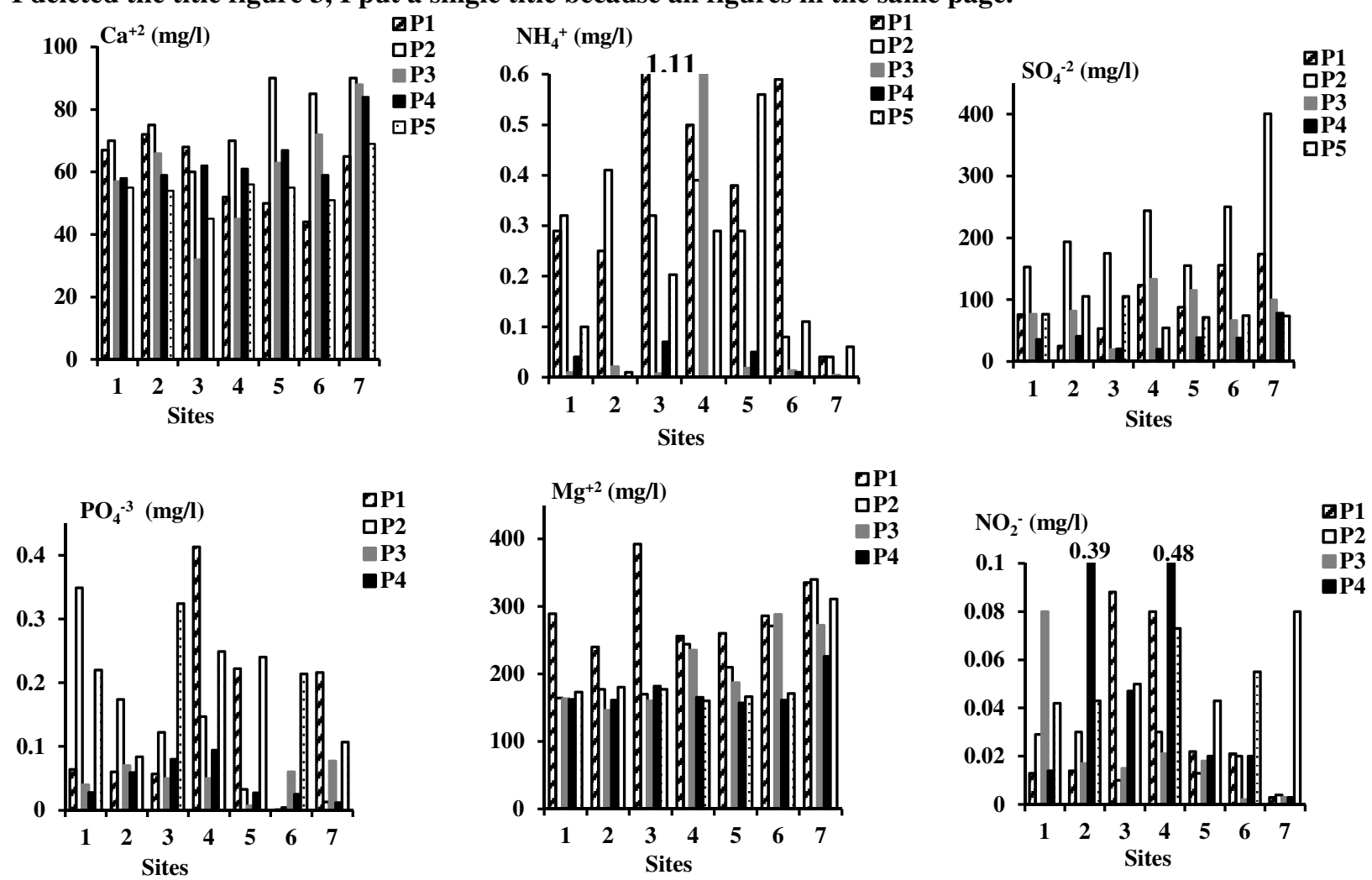

Fig.-2: Temporal and Spatial Variations of Water Quality in the Guenitra Dam From February to May 2017 ( $\mathrm{P}=$ Picking Point). 
The Total Hardness values were far less than the recommended values and hence the water can safely be used for domestic and agricultural purposes.

\section{Nutriments}

Phosphorus is the first limiting nutrient for plants in freshwater ${ }^{21}$. Which regulates the phytoplankton production in the presence of nitrogen. It is available in the form of phosphate $\left(\mathrm{PO}_{4}^{-3}\right)$ in natural waters and generally occurs in low to moderate concentration. Agriculture runoff containing phosphate fertilizers as well as the waste water containing the detergents etc. tend to increase $\mathrm{PO}_{4}^{-3}$ pollution in water ${ }^{22}$. High levels of phosphate may originate from municipal wastewater discharges since it is an important component of detergents ${ }^{23}$. Phosphorus is frequently the limiting nutrient for plant growth in freshwater systems and plays a key role in eutrophication. The increase in phosphorus concentrations in the running waters leads to eutrophication. ${ }^{24,25}$ A major source of phosphate in water is domestic sewage, agriculture effluents and industrial waste waters. The high concentration of phosphate is, therefore, indicative of pollution. In $0.349 \mathrm{mg} / \mathrm{l}$ at Station-1 in the month of March.The presence of nitrite is an indicator of wastewater pollution in water. The $\mathrm{NO}_{2}$ concentration in the river varied from 0.002 to $0.476 \mathrm{mg} / \mathrm{l}$. Site 4 showed the highest values of $\mathrm{NO}_{2}$ because of wastewater discharges from OumToub. Nitrite concentrations at all sites were below the maximum permissible level of $1 \mathrm{mg} / \mathrm{l}$ for drinking water (Algerian standards $=0.5 \mathrm{mg} / \mathrm{l}$ ).

\section{CONCLUSION}

In this study, a detailed physicochemical analysis was carried out to assess the quality of Guenitra dam water. The results of the physicochemical analyzes of the waters show that the overall quality of these waters is generally good. Concerning the increase of nitrite in station 3 and ammonium in stations 2 and 4 is explained by the presence of sewage and aquatic living beings according to our report in situ (fish, plant .....etc.) and the use of chemical and natural fertilizers (animal droppings). The analysis report clearly indicates that the water after treatment can be reused in irrigation and drinking. Hence regular water quality monitoring is desirable to develop a strategy to control the environmental hazards due to these elements and to recover environmental security of dam Guenitra.

\section{REFERENCES}

1. K. Karthik, R. Mayildurai, R. Mahalakshmi and S. Karthikeyan, Rasayan J. Chem,12 (2), 409(2019), DOI: http://dx.doi.org/10.31788/RJC.2019.1225005.

2. M. Benblidia, L'efficacité d'utilisation de l'eau et approach économique. Etude nationale, Algérie. CAR/PNUE/PAM, Plan Bleu, Sophia Antipolis, 24 (2011).

3. B. Remini,Larhyss Journal,8, 27(2010).

4. W. Boudraa, M. Dhia, E. Khemis, O. Boumaaza, Z. Bouslama, G. Merzougand, M. Houhamdi, Qualité bactériologique et physicochimique de l'eau des plagesd'Annaba. $1^{\text {er }}$ Séminaire National sur la Santé et bio-surveillance des écosystèmes aquatiques, Souk Ahras, Algeria, (2014).

5. S. Ben Rabah, Ph. D. Thesis, UniversitéBadji Mokhtar-Annaba, (2006).

6. T.R. Parsons,Y. Maita and C.M. Lalli, A Manual of Chemical and Biological Methods For Sea Water Analysis, Pergamon Press, Oxford, (1989).

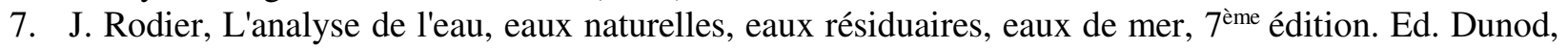
Paris, p 1526,(2009).

8. G. Matta, Journal of Chemical and Pharmaceutical Scienes,7(3), 210(2014).

9. V. Kumar, S. Arya, A. Dhaka, A. Minakshiand. Chanchal, International Multidisciplinary Research Journal, 1, 14(2011).

10. American Public Health Association (APHA), Standard Methods For the Examination of Water and Wastewater, (19 ${ }^{\text {th }}$ Edn). American Public Health Association, Washington DC, USA. (1995).

11. D. N. Saksena,R. K. Gargand, R. J. Rao, Journal of Environmental Biology,29(5), 701(2008).

12. A. Valipour, N. Hamnabard, K. S. Woo and Y. H. Ahn, Journal of Environmental Management, 145, 1(2014), DOI: 10.1016/j.jenvman.2014.06.009.

13. H. L. Yadav and A. Jamal, Rasayan J. Chem.,11(1), 46(2018), DOI: 10.7324/RJC.2018.1111961.

14. WHO, Guidelines for Drinking-Water Quality: Recommendations, 1(2004). 
RASĀYAN J. Chem.

Vol. 12 | No. 2 |827 - 832| April - June | 2019

15. AK. Verma and DN. Saksena, Asian J. Exp. Biol. Sci.,1, 155(2010).

16. P. Tambekar, P.P. Morey, R. J. Batra and RG. Weginwar, Journal of Chemical and Pharmaceutical Research,5, 27(2013).

17. A. K. Agarwal and G.S. Rajwar, India. J. Am. Sci., 6(6), 65(2010).

18. K. Kim JS. Lee CW. Oh GS. Hwang J. Kim S. Yeo Y. Kim andS. Park, Journal of Hydrology, 264, 147(2002), DOI: 10.1016/S0022-1694(02)00074-4.

19. D. Janardhana Rao, A.V. Swami, V.S, Raghu Babu K., B. HariBabu, Rasayan J. Chem.,9(3), 444(2016).

20. M. M. Shahataand, A. M. Thabet, International Journal of Advanced Research, 3(9), 184(2015), DOI: $10.21474 / \mathrm{IJAR} 01$.

21. R. Stickney, Aquaculture: An Introductory Text. CABI Publishing, UK, 265, (2005).

22. M. R. Singh,A. Gupta andK. H. Beeteswari, J. Appl. Sci. Environ. Manage,14(4), 85(2010), DOI: 10.4314/jasem.v14i4.63263.

23. M. Vega, R. Pardo, E. Barradoand, L. Debaâ., Wat. Res.,32(12), 3581(1998), DOI: 10.1016/S00431354(98)00138-9.

24. T. Davie, Fundamentals of Hydrology, Routledge: New York, (2003).

25. P.R. Kannel, S., Lee, S.R. Kanel, SP. Khan and Y.S. Lee, Environmental Monitoring and Assessment,129, 433(2007), DOI: 10.1007/s10661-006-9375-6.

[RJC-5223/2019] 